\title{
PENDIDIKAN DAN PENGEMBANGAN KARAKTER BANGSA
}

\author{
Ronggo Warsito, M.Pd.', Ike Anisa \\ E-mail: ronggo_warsito@unwidha.ac.id ${ }^{1}$ \\ ikeanisa@unwidha.ac.id²
}

\section{PENDAHULUAN}

\section{A. Latar Belakang}

Bangsa Indonesia yang telah memproklamasikan kemerdekaan pada tanggal 17 Agustus 1945, dalam perkembangannya memiliki kondisi yang unik. Sudah 67 tahun bangsa Indonesia menjalani kehidupan bernegara secara merdeka yang telah diakui bangsa-bangsa lain di dunia internasional. Keunikan bangsa Indonesia tidak saja tampak dari keberagaman komponen budaya, agama yang dianut, suku, dan kekayaan yang dimiliki bangsa ini.

Dilihat dari kekayaan yang dimiliki bangsa Indonesia dapat dikategorikan sangat melimpah disertai dengan letak kepulauan yang berada di lintasan khatulistiwa. Selain itu juga tanah yang subur, air yang melimpah, udara yang segar, kekayaan sumber energi dan mineral yang melimpah di tanah dan laut, semuanya memberikan keunikan bagi bangsa Indonesia. Selain itu, keunikan juga dapat kita lihat dari kondisi yang ada, dirasakan, dan telah menjadi ciri khas bangsa ini.

Dengan kondisi sosial budaya dan kekayaan yang melimpah, semestinya bangsa Indonesia merasakan kehidupan yang makmur dan sejahtera. Namun, kenyataan menunjukkan lain dari logika. Kekayaan alam terekspoitasi besar-besaran, pembangunan industri terjadi terus-menerus, pergantian pemerintahan berjalan lancar, tetapi kebanyakan rakyat Indonesia belum mendapatkan kehidupan yang makmur dan merata. 
* Makalah Disampaikan dalam Forum Silaturahmi Keakraban (Sikrab) Program Studi Pendidikan Pancasila dan Kewarganegaraan dengan Tema "Urgensi Pendidikan Karakter Bangsa bagi Mahasiswa sebagai Pilar Kehidupan Bangsa” pada Hari Rabu, 24 Oktober 2012

** Staf Pengajar Program Studi PPKn Universitas Widya Dharrna Klaten

Berbagai kondisi dan pengalaman di atas, menunjukkan bahwa bangsa Indonesia merupakan bangsa yang unik. Unik merujuk pada kondisi yang dialami bangsa Indonesia hingga saat ini. Banyak orang dan pihak-pihak bertanya, “apa yang salah dengan bangsa ini?” Beberapa indikasi tentang apa yang salah dengan bangsa ini dapat dilaporkan beberapa hal antara lain kondisi moral/ akhlak bangsa yang hancur, seperti terjadinya seks bebas, penggunaan narkoba, KKN, dan sebagainya.

Bangsa Indonesia sekarang mulai sadar, betapa pentingnya pendidikan nilai, budaya, dan karakter bangsa. Pendidikan nilai yang dahulu diwadahi salah satunya dengan Pendidikan Pancasila dan Kewarganegaraan, di Era reformasi justru mulai ditinggalkan. Mata pelajaran di sekolah-sekolah sudah menghapus Pendidikan Pancasila, tinggal Pendidikan Kewarganegaraan dengan jam pelajaran yang minim. Sekarang bangsa Indonesia sudah mulai sadar, betapa pentingnya keberadaan pendidikan yang mampu membentuk moral, etika, dan karakter bangsa Indonesia.

Berangkat dari pemikiran di atas, maka dalam paper ini akan dikaji beberapa hal pertama, definisi pendidikan karakter, kedua, tujuan pendidikan karakter, ketiga, Upaya-upaya yang dapat dilakukan guna meningkatkan karakter atau akhlak terpuji, keempat nilai-nilai apa saja yang perlu diperkuat untuk pembangunan bangsa, dan kelima peranan pendidikan karakter bagi pembangunan bangsa. Dengan uraian tersebut, diharapkan kita semakin sadar bagaimana pentingnya pendidikan budaya dan karakter bangsa.

\section{B. Perumusan Masalah}

Beberapa permasalahan yang diangkat dalam paper ini adalah sebagai berikut.

1. Bagaimana definisi pendidikan karakter?

2. Apa sajakah tujuan pendidikan karakter? 
3. Upaya-upaya apa saja yang dapat dilakukan guna meningkatkan karakter atau akhlak terpuji?

4. Nilai-nilai apa saja yang perlu diperkuat untuk pembangunan bangsa?

5. Bagaimanakah peranan pendidikan karakter bagi pembangunan bangsa?

C. Tujuan Penulisan

Dengan mengacu kepada rumusan masalah sebagaimana tersebut di atas, maka penulisan paper ini mempunyai tujuan sebagai berikut.

1. Untuk mengetahui definisi pendidikan karakter.

2. Untuk memahami tujuan pendidikan karakter.

3. Untuk mengetahui upaya-upaya apa saja yang dapat dilakukan guna meningkatkan karakter atau akhlak terpuji.

4. Untuk memahami nilai-nilai apa saja yang perlu diperkuat untuk pembangunan bangsa.

5. Untuk memahami peranan pendidikan karakter bagi pembangunan bangsa.

\section{DEFINISI PENDIDIKAN KARAKTER}

Pendidikan karakter merupakan sebuah istilah yang semakin hari semakin mendapatkan pengakuan dari masyarakat Indonesia. Hal ini akan semakin tampak dengan dirasakannya berbagai ketimpangan hasil pendidikan dilihat dari perilaku lulusan pendidikan formal saat ini, korupsi, maraknya seks bebas di kalangan remaja, narkoba, tawuran, pembunuhan, dan perampokan.

Istilah pendidikan karakter berasal dari dua kata, yakni kata pendidikan dan karakter. Menurut Undang-Undang Sistem Pendidikan Nasional, Pendidikan disebutkan bahwa pendidikan adalah usaha sadar dan terencana untuk mewujudkan suasana belajar dan proses pembelajaran agar peserta didik secara aktif mengembangkan potensi dirinya untuk memiliki kekuatan spiritual keagamaan, pengendalian diri, kepribadian, kecerdasan, akhlak mulia, serta keterampilan yang diperlukan dirinya, masyarakat, bangsa, dan negara (Pasal 1 ayat (1) Undang-Undang Nomor 20 Tahun 2003). 
Kata karakter dalam Kamus Besar Bahasa Indonesia tidak ditemukan. Karakter adalah istilah serapan dari bahasa Inggris character. Karakter adalah kata benda yang memiliki arti 1) kualitas-kualitas pembeda, 2) kualitaskualitas positif, 3) reputasi, 4) individu dalam kaitannya dengan kepribadian, tingkah laku atau tampilan (Dharma Kesuma, dkk. 2011: 23). Menurut penulis karakter adalah segala sesuatu yang berhubungan dengan budi pekerti, tingkah laku, tata susila, etika, dan yang sejenis.

Dalam wacana dengan pendidikan, kata karakter terutama berkenaan dengan orang. Karakter berkenaan dengan kualitas, bukan kuantitas. Karakter berhubungan dengan daya pembeda atau pembatas, membatasi atau membedakan yang satu dengan yang lain, membedakan masyarakat yang satu dengan masyarakat yang lain. Karakter dapat merujuk pada kualitas positif maupun negatif. Kesimpulannya, bahwa karakter adalah sebuah kata yang merujuk pada kualitas orang dengan karakteristik tertentu.

Hurlock (1974: 8) dalam bukunya Personality Development, secara tidak langsung mengungkapkan bahwa karakter terdapat pada kepribadian. Karakter mengimplikasikan sebuah standar moral dan melibatkan sebuah pertimbangan nilai. Karakter berkaitan dengan tingkah laku yang diatur oleh upaya dan keinginan. Hati nurani, sebuah unsur esensial dari karakter, adalah sebuah pola kebiasaan yang mengontrol tingkah laku seseorang, membuatnya selaras dengan pola-pola kelompok yang diterima secara sosial. Definisi karakter dari Hurlock, sementara ini dapat digunakan untuk menganalisis secara lebih jauh tentang karakter dan implikasinya.

Beberapa masalah ketidaktepatan makna yang beredar di masyarakat mengenai makna pendidikan karakter dapat diidentifikasi diantaranya sebagai berikut.

1. Pendidikan karakter $=$ mata pelajaran agama dan $\mathrm{PKn}$, karena itu menjadi tanggung jawab guru agama dan PKn.

2. Pendidikan karakter $=$ mata pelajaran pendidikan budi pekerti, sehingga menjadi tanggunga jawab guru yang bersangkutan. 
3. Pendidikan karakter $=$ pendidikan yang menjadi tanggung jawab keluarga, bukan tanggung jawab sekolah.

4. Pendidikan karakter = adanya penambahan mata pelajaran baru dalam KTSP (Dharma Kesuma, 2011: 5).

Berbagai Makna pendidikan karakter sebagaimana tersebut di atas, bermunculan dan berkembang dalam pemikiran banyak orang, guru, maupun masyarakat umum. Menurut Djoko Dwiyanto (2012: 34), dalam pendidikan karakter manusia dipandang sebagai yang mampu mengatasi determinasi di luar dirinya. Manusia bertindak dan mampu mengatasi keterbatasan dirinya karena ia memiliki nilai yang berharga dan layak untuk diperjuangkan.

Berikut ini disampaikan definisi pendidikan karakter menurut para pakar agar lebih jelas dalam pembahasan selanjutnya. Menurut Ratna Megawangi (2004: 95), "pendidikan karakter adalah sebuah usaha untuk mendidik anak-anak agar dapat mengambil keputusan dengan bijak dan mempraktekkannya dalam kehidupan sehari-hari, sehingga mereka dapat memberikan kontribusi yang positif kepada lingkungannya." Definisi lain dikemukakan oleh Fakry Gaffar (2010: 1), pendidikan karakter adalah sebuah proses transformasi nilai-nilai kehidupan untuk ditumbuhkembangkan dalam kepribadian seseorang sehingga menjadi satu dalam perilaku kehidupan orang itu." Dalam definisi tersebut terdapat tiga pikiran penting yakni 1) proses transformasi nilai, 2) ditumbuhkembangkan dalam kepribadian, 3) menjadi satu dalam perilaku.

Pendapat lain dikemukakan oleh Dharma Kesuma dkk. (2011: 5-6), bahwa pendidikan karakter dalam seting sekolah sebagai "pembelajaran yang mengarah pada penguasaan dan pengembangan perilaku anak secara utuh yang didasarkan pada suatu nilai tertentu yang dirujuk oleh sekolah.” Dalam definisi yang dikemukakan oleh Dharma Kesuma mengandung tiga makna yakni 1) pendidikan karakter merupakan pendidikan yang terintegrasi dengan pembelajaran yang terjadi pada semua mata pelajaran, 2) diarahkan pada penguatan dan pengembangan perilaku anak secara utuh. Asumsinya anak merupakan organisme manusia yang memiliki potensi untuk dikuatkan dan 
dikembangkan, 3) penguatan dan pengembangan perilaku didasari oleh nilai yang dirujuk sekolah (lembaga). Melihat definisi tersebut di atas, maka semua mata pelajaran juga diharapkan menyampaikan pesan akan pentingnya karakter bangsa.

\section{TUJUAN DAN FUNGSI PENDIDIKAN KARAKTER}

Pada hakikatnya, tujuan pendidikan nasional tidak boleh melupakan landasan konseptual filosofi pendidikan yang mampu menyiapkan generasi masa depan untuk dapat bertahan hidup (survive) dan berhasil menghadapi tantangan-tantangan zamannya. Fungsi dan tujuan pendidikan nasional menurut Undang-Undang Sistem Pendidikan Nasional Tahun 2003 Bab 2 Pasal 3 adalah sebagai berikut."Pendidikan nasional berfungsi mengembangkan kemampuan dan membentuk watak serta peradaban bangsa yang bermartabat dalam rangka mencerdaskan kehidupan bangsa, bertujuan untuk berkembangnya potensi peserta didik agar menjadi manusia yang beriman dan bertakwa kepada Tuhan Yang Maha Esa, berakhlak mulia, sehat, berilmu, cakap, kreatif, mandiri, dan menjadi warga negara yang demokratis serta bertanggung jawab (Undang-Undang No. 20 Tahun 2003).

Mencermati fungsi pendidikan nasional, yakni mengembangkan kemampuan dan membentuk watak serta peradaban bangsa seharusnya memberikan pencerahan yang memadai bahwa pendidikan harus berdampak pada watak manusia atau bangsa Indonesia. Fungsi ini amat berat untuk dipikul oleh pendidikan nasional, terutama apabila dikaitkan dengan siapa yang bertanggung jawab untuk keberlangsungan fungsi ini.

Fungsi pertama "Mengembangkan kemampuan" dapat dipahami bahwa pendidikan nasional menganut aliran konstruktivisme, yang mempercayai bahwa peserta didik adalah manusia yang potensial dan dapat dikembangkan secara optimal melalui proses pendidikan. Setiap layanan pendidikan yang ada di Indonesia harus dipersepsi secara sama bahwa peserta didik itu memiliki potensi yang luar biasa dan perlu difasilitasi melalui proses pendidikan untuk mengembangkan potensinya. 
Dalam konteks pendidikan karakter, kita lihat bahwa kemampuan yang harus dikembangkan pada peserta didik melalui persekolahan adalah berbagai kemampuan yang akan menjadikan manusia sebagai makhluk yang berketuhanan dan mengemban amanah sebagai pemimpin di dunia. Kemampuan yang perlu dikembangkan pada peserta didik adalah kemampuan mengabdi kepada Tuhan yang menciptakannya, kemampuan untuk menjadi dirinya sendiri, kemampuan untuk hidup secara harmonis dengan manusia dan makhluk lainnya, dan kemampuan untuk menjadikan dunia ini sebagai wahana kemakmuran dan kesejahteraan bersama.

Fungsi kedua pendidikan nasional adalah "membentuk watak" mengandung makna bahwa pendidikan nasional harus diarahkan pada pembentukan watak. Pendidikan yang berorientasi pada watak peserta didik merupakan suatu hal yang tepat, tetapi perlu diperjelas mengenai istilah perlakuan terhadap "watak." Apakah watak itu harus "dikembangkan", “dibentuk" atau “difasilitasi." Perspektif pedagogik, lebih memandang bahwa pendidikan itu mengembangkan/ menguatkan/ memfasilitasi watak, bukan membentuk watak. Jika watak dibentuk, maka tidak ada proses pedagogik/ pendidikan, yang terjadi adalah pengajaran (Dharma Kesuma, dkk., 2011: 7).

Ukuran keberhasilan pendidikan yang berhenti pada angka ujian, seperti halnya ujian nasional, adalah sebuah kemunduran, karena dengan demikian pembelajaran akan menjadi sebuah proses menguasai keterampilan dan mengakumulasi pengetahuan. Paradigma ini menempatkan peserta didik sebagai pelajar imitatif dan belajar dari ekspose-ekspose didaktik yang akan berhenti pada penguasaan fakta, prinsip, dan aplikasinya. Paradigma ini tidak sesuai dengan esensi pendidikan yang digariskan dalam Undang-Undang Sistem Pendidikan Nasional.

Apa tujuan pendidikan karakter dalam seting sekolah? Pendidikan karakter dalam seting sekolah memiliki tujuan sebagai berikut,

1. Menguatkan dan mengembangkan nilai-nilai kehidupan yang dianggap penting dan perlu sehingga menjadi kepribadian/ kepemilikan peserta didik yang khas sebagaimana nilai-nilai yang dikembangkan. Penguatan 
dan pengembangan memiliki makna bahwa pendidikan dalam seting sekolah bukanlah sekedar dogmatisasi nilai kepada peserta didik, tetapi sebuah proses yang membawa peserta didik untuk memahami dan merefleksi bagaimana suatu nilai menjadi penting untuk diwujudkan dalam perilaku keseharian.

2. Mengoreksi perilaku peserta didik yang tidak bersesuaian dengan nilainilai yang dikembangkan oleh sekolah.Tujuan ini memiliki makna bahwa pendidikan karakter memiliki sasaran untuk meluruskan berbagai perilaku anak yang negatif menjadi positif. Proses pelurusan yang dimaknai sebagai pengkoreksian perilaku dipahami sebagai proses yang pedagogis, bukan suatu pemaksaan atau pengkondisian yang tidak mendidik.

3. Membangun koneksi yang harmonis dengan keluarga dan masyarakat dalam memerankan tanggung jawab pendidikan karakter secara bersamasama. Tujuan ini memiliki makna bahwa proses pendidikan karakter di sekolah harus dihubungkan dengan proses pendidikan di keluarga. Jika pendidikan karakter di sekolah hanya bertumpu pada interaksi antara peserta didik dengan guru di kelas dan sekolah, maka pencapaian berbagai karakter yang diharapkan sulit diwujudkan.

\section{UPAYA-UPAYA YANG DAPAT DILAKUKAN GUNA MENINGKAT- KAN KARAKTER ATAU AKHLAK TERPUJI}

Peningkatan karakter atau akhlak yang terpuji dapat dilaksanakan melalui hal-hal sebagai berikut.

1. Muhasabah, yaitu selalu menghitung perbuatan yang telah dilakukannya selama ini, baik perbuatan buruk beserta akibat yang ditimbulkannya, atau pun perbuatan baik beserta akibat yang ditimbulkan olehnya.

2. Mu'aqobah, memberikan hukuman terhadap berbagai perbuatan dan tindakan yang telah dilakukannya. Hukuman ini tentu bersifat ruhiyah, seperti melakukan shalat sunah yang lebih banyak jika dibanding biasanya, berdzikir, dan sebagainya. 
3. Mu'ahadah, perjanjian dengan hati nurani (batin), untuk tidak mengulangi kesalahan dan keburukan tindakan yang dilakukan serta menggantinya dengan perbuatan baik.

4. Mujahadah, berusaha maksimal melakukan perbuatan yang baik untuk mencapai derajat ihsan, sehingga mampu mendekatkan diri pada Allah Swt. (muraqobah). Hal ini dilakukan dengan kesungguhan dan perjuangan keras, karena perjalanan untuk mendekatkan diri kepada Allah banyak rintangannya (Zubaedi, 2011: 119).

Secara lebih terperinci, proses untuk membangun karakter bisa menggunakan 7 tahapan. Menurut Asifin (2001: 1), tujuh tahapan itu meliputi muatabah, muroqobah, mujahadah, musyahadah, mukasyafah, muhabbah, dan ma'rifah.

Penjelasan 7 Tahapan Membangun Karakter

1. Muatabah atau penyesalan, yakni meninggalkan dosa-dosa seketika dan bertekad untuk tidak melakukannya lagi atau meninggalkan maksiat menuju taubat. Taubat dalam hal ini adalah taubat nasuhah, yakni taubat yang sesungguhnya yaitu suatu upaya untuk menjauhi dan tidak mengulangi perbuatan dosa yang pernah dilakukan untuk kedua kalinya.

2. Muroqobah, awas-mengawasi, maksudnya bahwa Tuhan selalu melihat kita. Kita yakin dengan sepenuh hati bahwa Allah selalu mendengar, mengetahui dan mengawasi kita.

3. Mujahadah, dalam definisi kajian tasawuf, adalah pengendalian atau kontrol terhadap nafsu dari hal-hal yang menggiurkan, dan upaya melawan hawa nafsu itu dilaksanakan pada setiap saat.

4. Musyahadah, adalah tindak lanjut dari ajaran ihsan yang mengajarkan konsep ibadah yang sesungguhnya dengan suatu ukuran "seakan-akan seorang hamba melihat Tuhan-nya, atau kalau seperti itu pastinya bahwa Allah melihat hamba-Nya.

5. Mukasyafah, secara bahasa mempunyai arti terbukanya tirai, yakni terbukanya segala rahasia alam yang tersembunyi atau terbukanya pengertian dan hal-hal yang bersifat ghaib. 
6. Muhabah, yang secara harfiah berarti cinta. Cinta pada hakikatnya berangkat dari ketulusan, keikhlasan, dan kesucian yang menghasilkan sikap al-uns (suka cita secara kejiwaan).

7. Ma'rifah, adalah sebuah anugerah pemberian langsung dari Allah Swt kepada hamba yang ia kehendaki. Pada tingkat inilah seorang hamba benar-benar akan mengetahui kebenaran tentang Tuhan.

\section{NILAI-NILAI YANG PERLU DIPERKUAT UNTUK PEMBANGUN- AN BANGSA}

Nilai adalah keyakinan yang membuat seseorang bertindak atas dasar pilihannya. Definisi ini dikemukakan oleh Gordon Allport (1964), seorang ahli psikologi kepribadian. Bagi Allport, nilai terjadi pada wilayah psikologis yang disebut keyakinan. Keyakinan ditempatkan sebagai wilayah psikologi yang lebih tinggi dari wilayah lainnya seperti hasrat, motif, sikap, keinginan , dan kebutuhan. Karena itu, keputusan benar-salah, baik-buruk, indah-tidak indah pada wilayah ini merupakan hasil dari serentetan proses psikologis yang kemudian mengarahkan individu pada tindakan dan perbuatan yang sesuai dengan nilai pilihannya (Rohmat Mulyana, 2011: 9).

Nilai adalah patokan normatif yang mempengaruhi manusia dalam menentukan pilihannya diantara cara-cara tindakan alternatif (Kupperman, 1983). Definisi ini memiliki tekanan utama pada norma sebagai faktor eksternal yang mempengaruhi perilaku manusia. Kupperman memandang norma sebagai salah satu bagian terpenting dari kehidupan sosial, sebab dengan penegakan norma seseorang justru dapat merasa tenang dan terbebas dari segala tuduhan masyarakat yang akan merugikan dirinya.

Definisi nilai yang lebih umum, dalam arti tidak memiliki tekanan pada sudut pandang tertentu adalah definisi yang dikemukakan oleh Hans Jonas (Bertens, 1999). Ia mengatakan bahwa nilai adalah alamat sebuah kata "ya" (value is address of a yess), atau kalau diterjemahkan secara kontekstual, nilai adalah sesuatu yang ditunjukkan dengan kata “ya."Definisi ini merupakan definisi yang memiliki kerangka lebih umum dan luas daripada dua definisi sebelumnya (dari Gordon Allport dan Kupperman). 
Untuk kebutuhan pengertian nilai yang lebih sederhana namun mencakup keseluruhan aspek yang terkandung dari tiga definisi di atas, dapat ditarik suatu definisi baru tentang nilai, yaitu nilai adalah rujukan dan keyakinan dalam menentukan pilihan (Rohmat Mulyana, 2011: 11). Kalau dibandingkan dengan definisi nilai dari Hans Jonas, definisi baru ini secara eksplisit menyertakan proses pertimbangan nilai, tidak hanya sekedar alamat dari sebuah kata "ya".

Setelah memahami pengertian nilai, selanjutnya akan dibahas nilainilai yang perlu diperkuat untuk pembangunan bangsa itu apa saja. Dalam penjelasan Pusat Pengkajian Pedagogik Universitas Pendidikan Indonesia (P3 UPI) nilai-nilai yang perlu diperkuat untuk pembangunan bangsa saat ini adalah sebagai berikut.

1. Jujur

2. Kerja keras

3. Ikhlas (Dharma Kesuma, 2011: 16-21).

Penjelasan:

1. Kejujuran

Jujur merupakan sebuah karakter yang dianggap dapat membawa bangsa Indonesia menjadi bangsa yang bebas dari korupsi, kolusi, dan nepotisme (KKN). Menurut Kamus Besar Bahasa Indonesia, jujur mengandung makna 1) lurus hati, tidak berbohong (misal dengan berkata apa adanya); 2) tidak curang (misal di permainan, dengan mengikuti aturan yang berlaku); 3) tulus, ikhlas (Hasan Alwi dkk., 2001: 479).

Jujur sebagai sebuah nilai merupakan keputusan seseorang untuk mengungkapkan (dalam bentuk perasaan, kata-kata dan/atau perbuatan) bahwa realitas yang ada tidak dimanipulasi dengan cara berbohong atau menipu orang lain untuk keuntungan dirinya. Kata jujur identik dengan "benar" yang lawan katanya adalah "bohong”. Makna jujur lebih jauh dikorelasikan dengan kebaikan (kemaslahatan). Kemaslahatan memiliki makna kepentingan orang banyak, bukan kepentingan diri sendiri atau kelompoknya, tetapi semua orang yang terlibat. 
Dalam konteks pembangunan karakter di sekolah, kejujuran menjadi amat penting untuk menjadi karakter anak-anak Indonesia saat ini. Karakter ini dapat dilihat secara langsung di kelas, semisal ketika anak melaksanakan ujian. Perbuatan mencontek merupakan perbuatan yang mencerminkan anak tidak berbuat jujur. Dengan mencontek, anak menipu diri, teman, orang tua, dan gurunya. Anak memanipulasi nilai yang didapatkannya seolah-oleh merupakan kondisi yang sebenarnya dari kemampuannya, padahal yang didapatnya bukan merupakan kondisi yang sebenarnya.

Di bawah ini dikemukakan ciri-ciri orang yang jujur. Orang yang memiliki karakter jujur dicirikan oleh perilaku sebagai berikut.

a. Jika bertekad (inisiasi keputusan) untuk melakukan sesuatu, tekadnya adalah kebenaran dan kemaslahatan;

b. Jika berkata tidak berbohong (benar apa adanya);

c. Adanya kesamaan antara yang dikatakan hatinya dengan apa yang dilakukannya (Dharma Kesuma, dkk., 2011: 17).

Seseorang yang memiliki karakter jujur aka diminati orang lain, baik dalam konteks persahabatan, bisnis, rekan atau mitra kerja, dan sebagainya. Karakter jujur ini merupakan salah satu karakter pokok untuk menjadikan seseorang cinta kebenaran, apapun resiko yang akan diterima dirinya dengan kebenaran yang ia lakukan.

2. Kerja keras

Kerja keras adalah suatu istilah yang melingkupi suatu upaya yang terus dilakukan (tidak pernah menyerah) dalam menyelesaikan pekerjaan yang menjadi tugasnya sampai tuntas. Kerja keras bukan berarti bekerja sampai tuntas lalu berhenti. Istilah yang dimaksud mengarah pada visi besar yang harus dicapai untuk kebaikan/ kemaslahatan manusia dan lingkungannya.

Dalam sekala mikro, kerja keras terjadi untuk kemaslahatan diri, keluarga, RT, RW, desa/ kelurahan. Pada sebagian orang, kerja keras dilakukan dengan menghabiskan waktu untuk membuat ide baru dan menyisihkan waktunya hanya 2 jam untuk tidur. Pada sebagian orang lagi, 
kerja keras dilakukan dengan cara pergi pagi pulang petang (P4) untuk menghidupi keluarganya, dan sebagainya. Kondisi variatif ini memiliki satu esensi yang sama, yaitu bagaimana memberikan kebaikan/ kemaslahatan kepada manusia dan lingkungannya. Tidak dikategorikan sebagai kerja keras orang yang menghabiskan waktunya untuk mengedarkan narkoba, ide merampok bank. Keduanya dilakukan bukan untuk memberikan kebaikan kepada manusia.

Saat ini begitu banyak pemuda yang merupakan penduduk produktif lebih memilih bekerja ringan. Tengoklah berapa banyak pemuda yang meminta-minta di terminal, atau di perempatan jalan; padahal bersamaan dengan keberadaan mereka, para kakek dan nenek masih terus bekerja keras, misalnya berjualan keliling.

Beberapa karakteristik kerja keras adalah perilaku yang dicirikan oleh kecenderungan sebagai berikut.

a. Merasa risau jika pekerjaannya belum terselesaikan sampai tuntas;

b. Mengecek/ memeriksa terhadap apa yang harus dilakukan atau apa yang menjadi tanggung jawabnya dalam suatu jabatan/ posisi;

c. Mampu mengelola waktu yang dimilikinya;

d. Mampu mengorganisasi sumber daya yang ada untuk menyelesaikan tugas dan tanggung jawabnya (Dharma Kesuma, 2011: 19-20).

3. Keikhlasan

Ikhlas dalam bahasa Arab memiliki arti "murni", "suci", "tidak bercampur", "bebas" atau "pengabdian yang tulus".Menurut ajaran Islam ikhlas berarti setiap kegiatan yang kita kerjakan semata-mata hanya karena mengharapkan ridha Allah Swt. Menurut Kamus Besar Bahasa Indonesia, ikhlas adalah bersih hati; tulus hati. Keikhlasan berarti ketulusan hati; kejujuran; kerelaan (Hasan Alwi, 2001: 420).

Di bawah ini dipaparkan beberapa definisi ikhlas yakni sebagai berikut. 
a. Menjadikan tujuan hanyalah untuk Allah tatkala beribadah, yaitu jika engkau sedang beribadah maka hatimu dan wajahmu engkau arahkan kepada Allah bukan kepada manusia.

b. Membersihkan amalan dari komentar manusia, yaitu jika engkau sedang melakukan suatu amalan tertentu maka engkau membersihkan dirimu dari memperhatikan manusia untuk mengetahui apakah perkataan mereka tentang perbuatan itu.

c. Samanya amalan-amalan seorang hamba antara yang nampak dengan yang ada di batin.

d. Melupakan pandangan manusia dengan selalu memandang kepada Allah (http://www.al-islam.agussuwasono.com/artikel/aqidah/303-ikhlas-danbahaya-riya-html).

Berikut ini dikemukakan ciri-ciri orang ikhlas sebagai berikut.

a. Terjaga dari segala sesuatu yang diharamkan Allah Swt., baik sedang bersama manusia mapun sendiri.

b. Senantiasa beramal di jalan Allah baik sedang sendirian atau bersama orang lain, baik ada pujian atau .

c. Selalu menerima apa adanya yang diberikan Allah.

d. Mudah memaafkan kesalahan orang lain (http://sites.google.com/site/ otoehkasela/ ikhlas-menurut-islam)

\section{PERANAN PENDIDIKAN KARAKTER BAGI PEMBANGUNAN BANGSA}

Pendidikan menduduki posisi sentral dalam pembangunan karena sasarannya adalah peningkatan kualitas SDM. Oleh sebab itu pendidikan juga merupakan alur tengah pembangunan dari seluruh sektor pembangunan (Umar Tirtarahardja, 2005: 300). Terdapat suatu kesan bahwa persepsi masyarakat umum tentang arti pembangunan lazimnya bersifat menjurus pada pembangunan fisik. Pembangunan semata-mata hanya beruang lingkup pembangunan material atau pembangunan fisik berupa pembangunan gedung, jembatan, pabrik, dan lain-lain. Padahal sukses tidaknya pembanguan fisik itu 
justru sangat ditentukan oleh keberhasilan pembangunan ruhaniah/ spiritual; yang secara bulat diartikan pembangunan manusia, dan ini menjadi tugas utama pendidikan.

Persepsi yang keliru tentang arti pembangunan yang menganggap bahwa pembangunan itu hanya semata-mata pembangunan material dapat berdampak menghambat pembangunan sistem pendidikan, sebab yang benar pembangunan harus bersifat komprehensif. Persepsi yang mengatakan bahwa pembangunan diasosiasikan dengan pembangunan ekonomi dan industri, sementara pembangunan SDM tidak secara langsung terlihat, maka akan menimbulkan gejala penyerta yang negatif, antara lain kegoncangan sosial politik. Ini menuinjukkan bahwa pembangunan dalam arti yang terbatas pada bidang ekonomi dan industri saja belum menggambarkan esensi pembangunan yang sebenarnya.

Saat proklamasi kemerdekaan Indonesia tanggal 17 Agustus 1945, the founding fathers atau para bapak pendiri bangsa menyadari bahwa paling tidak ada tiga tantangan besar yang harus dihadapi. Pertama, adalah mendirikan negara yang bersatu dan berdaulat, kedua, adalah membangun bangsa, dan ketiga, membangun karakter (Muchlas Samani, 2012: 1). Ketiga tantangan tersebut secara jelas tampak dalam konsep "Negara Bangsa (nationstate) dan pembangunan karakter bangsa (nation and character building).

Salah satu bapak pendiri bangsa, adalah presiden pertama Republik Indonesia, Ir. Soekarno, menegaskan bahwa "Bangsa ini harus dibangun dengan mendahulukan pembangunan karakter (character building), inilah yang akan membuat Indonesia menjadi bangsa yang besar, maju, dan jaya, serta bermartabat. Kalau character building ini tidak dilakukan, maka bangsa Indonesia akan menjadi bangsa kuli.” (Muchlas Samani, 2012: 2).

Pembangunan karakter bangsa di Indonesia dirasakan amat perlu pengembangannya apabila mengingat semakin meningkatnya tawuran antar pelajar, mahasiswa, serta bentuk-bentuk kenakalan remaja di kota-kota besar, penggunaan narkoba dan lain-lain. Ada hal yang memprihatinkan lagi yakni kegagalan "Kantin Kejujuran”. Keinginan untuk membangun sifat jujur pada 
anak dilakukan melalui kantin kejujuran di beberapa sekolah. Banyak kantin kejujuran yang bangkrut dan gagal karena belum bangkitnya sifat jujur pada anak-anak.

Disiplin dan tertib berlalu lintas, budaya antre, budaya baca, budaya hidup bersih dan sehat masih jauh dari standar. Di kota-kota besar, lampu merah seolah-olah kurang berfungsi. Jika tidak ada petugas, menyerobot lampu merah sering dilakukan. Kebanggaan kita terhadap jati diri dan kekayaan budaya sendiri masih rendah. Sebagai bangsa, kita masih mengidap inferiority complex nasional, terbukti masih suka dan melahap tanpa seleksi segala produk dan budaya asing.

Selanjutnya mari kita melihat beberapa indikasi tentang "apa yang salah dengan bangsa ini?”

Pertama, kondisi moral/ akhlak generasi muda banyak yang rusak/ hancur. Ini ditandai dengan maraknya seks bebas di kalangan remaja, peredaran narkoba, tawuran, peredaran foto dan video porno, dan sebagainya. Data hasil survey mengenai seks bebas di kalangan remaja Indonesia menunjukkan $63 \%$ remaja Indonesia melakukan seks bebas (www.wahdah.or.id/wis/index2.php?option=com_content\&do_pdf...) Adapun remaja korban narkoba di Indonesi ada 1,1 juta orang (http://hizbuttahrir.or.id/2009/12/01/jabar-masih-darurat-hivaids-dan-seks-bebas/.)

Kedua, pengangguran terdidik yang mengkhawatirkan (lulusan SMA. SMK, dan Perguruan Tinggi). Data Badan Pusat Statistik menyebutkan pengangguran lulusan SMK 17,26\%, SMA 14,31 \%, lulusan universitas 12,59 \%, Diploma I, II, III 11,21\% (http:www.tribunjabar.co.id/read/artikel/4317/ tentangkami).

Ketiga, rusaknya moral bangsa dan sudah menjadi akut (korupsi, asusila, kejahatan, tindakan kriminal. Keempat, bencana yang sering dan terus berulang dialami bangsa Indonesia, Kelima, kemiskinan yang mencapai 40 juta dan terus bertambah. Keenam, daya kompetitif yang rendah sehingga banyak produk dalam negeri dan SDM yang tergantikan oleh produk dan 
SDM yang tergantikan dari luar negeri. Ketujuh, Inefisiensi pembiayaan pendidikan.

Dari berbagai permasalahan dan kondisi yang sangat memprihatinkan tersebut, maka di sinilah letak pentingnya pendidikan budaya dan karakter bangsa. PKn atau Civic Education sebagai salah satu program pendidikan karakter, melakukan pembelajaran yang secara programatik-prosedural berupaya memanusiakan (humanizing) dan membudayakan (civillizing) serta memberdayakan (emprowering) manusia/ anak didik (diri dan kehidupannya) menjadi warga negara yang baik sebagaimana tuntutan keharusan / yuridis konstitusional bangsa/ negara Indonesia (Dasim Budimansyah (Editor), 2006: 9). Selain Pendidikan Kewarganegaraan, tidak kalah pentingnya adalah peran Pendidikan Pancasila. Warsito (2012: 23) dalam bukunya yang berjudul Pendidikan Pancasila Era Reformasi menyatakan bahwa melalui Pendidikan Pancasila, warga negara Republik Indonesia diharapkan mampu memahami, menganalisis, dan menjawab masalah-masalah yang dihadapi oleh masyarakat bangsanya secara berkesinambungan dan konsisten berdasarkan cita-cita dan tujuan bangsa Indonesia.

\section{KESIMPULAN}

Pendidikan karakter adalah sebuah usaha untuk mendidik anak-anak agar dapat mengambil keputusan dengan bijak dan mempraktekkannya dalam kehidupan sehari-hari, sehingga mereka dapat memberikan kontribusi yang positif kepada lingkungannya. Pendidikan karakter adalah sebuah proses transformasi nilai-nilai kehidupan untuk ditumbuhkembangkan dalam kepribadian seseorang sehingga menjadi satu dalam perilaku kehidupan orang itu. Dalam seting sekolah pendidikan karakter sebagai "pembelajaran yang mengarah pada penguasaan dan pengembangan perilaku anak secara utuh yang didasarkan pada suatu nilai tertentu yang dirujuk oleh sekolah.”

Pendidikan karakter dalam seting sekolah memiliki tujuan sebagai berikut, 1) menguatkan dan mengembangkan nilai-nilai kehidupan yang dianggap penting dan perlu, 2) mengoreksi perilaku peserta didik yang tidak 
bersesuaian dengan nilai-nilai yang dikembangkan oleh sekolah. 3) membangun koneksi yang harmonis dengan keluarga dan masyarakat dalam memerankan tanggung jawab pendidikan karakter secara bersamasama.

Peningkatan karakter atau akhlak yang terpuji dapat dilaksanakan melalui hal-hal sebagai berikut.1). Muhasabah, yaitu selalu menghitung perbuatan yang telah dilakukannya selama ini, 2) mu'aqobah, memberikan hukuman terhadap berbagai perbuatan dan tindakan yang telah dilakukannya, 3) Mu'ahadah, perjanjian dengan ahti nurani (batin), 4) Mujahadah, berusaha maksimal untuk melakukan perbuatan yang baik. Adapun proses untuk membangun karakter menggunakan 7 tahapan, yakni muatabah, muroqobah, mujahadah, musyahadah, mukasyafah, muhabbah, dan ma'rifah.

Dalam penjelasan Pusat Pengkajian Pedagogik Universitas Pendidikan Indonesia (P3 UPI) nilai-nilai yang perlu diperkuat untuk pembangunan bangsa saat ini adalah sebagai berikut 1) jujur, 2) kerja keras, 3) ikhlas.

Pembangunan karakter bangsa di Indonesia dirasakan amat perlu pengembangannya apabila mengingat semakin meningkatnya tawuran antarpelajar, mahasiswa, serta bentuk-bentuk kenakalan remaja di kota-kota besar, penggunaan narkoba dan lain-lain. Ada hal yang memprihatinkan lagi yakni kegagalan "Kantin Kejujuran”. Keinginan untuk membangun sifat jujur pada anak dilakukan melalui kantin kejujuran di beberapa sekolah. Banyak kantin kejujuran yang gagal karena belum bangkitnya sifat jujur.

Disiplin dan tertib berlalu lintas, budaya antre, budaya baca, budaya hidup bersih dan sehat masih jauh dari standar. Di kota-kota besar, lampu merah seolah-olah kurang berfungsi. Jika tidak ada petugas, menyerobot lampu merah sering dilakukan. Kebanggan kita terhadap jati diri dan kekayaan budaya sendiri masih rendah. Sebagai bangsa, kita masih mengidap inferiority complex nasional, terbukti masih suka dan melahap tanpa seleksi segala produk dan budaya asing.

Selanjutnya mari kita melihat beberapa indikasi tentang "apa yang salah dengan bangsa ini?" Pertama, kondisi moral/ akhlak generasi muda 
banyak yang rusak/ hancur. Kedua, pengangguran terdidik yang mengkhawatirkan. Ketiga, rusaknya moral bangsa dan sudah menjadi akut. Keempat, bencana yang sering dan terus berulang dialami bangsa Indonesia, Kelima, kemiskinan yang mencapai 40 juta dan terus bertambah. Keenam, daya kompetitif yang rendah, Ketujuh, Inefisiensi pembiayaan pendidikan. Dari berbagai permasalahan dan kondisi yang sangat memprihatinkan tersebut, maka di sinilah letak pentingnya pendidikan budaya dan karakter bangsa.

\section{DAFTAR PUSTAKA}

Alwi, Hasan, dkk. 2001. Kamus Besar Bahasa Indonesia-Edisi Ketiga. Jakarta: Balai Pustaka.

Asifin. 2001. Jalan Menuju Ma'rifatullah dengan Tahapan (7 M). Surabaya: Terbit Terang.

Dasim Budimansyah (Editor), 2006. Pendidikan Nilai Moral dalam Dimensi Pendidikan Kewarganegaraa. Bandung: Laboratorium Pendidikan Kewarganegaraan, FPIS- UPI.

Dwiyanto, Djoko dan Gatot Saksono. 2012. Pendidikan Karakter Berbasis Pancasila, Negara Pancasila: Agama atau Sekuler; Sosialis atau Kapitalis. Yogyakarta: Ampera Utama.

Gaffar, Mohammad Fakry. 2010. Pendidikan Karakter Berbasis Islam (Disampaikan pada Workshop Pendidikan Karakter Berbasis Agama, 8-10 April 2010 di Yogyakarta).

Hurlock, Elizabeth B. 1974. Personality Development. New York: McGraw-Hill Book Company.

Kesuma, Dharma. 2011. Pendidikan Karakter-Kajian Teori dan Praktek di Sekolah. Bandung: PT Remaja Rosdakarya Offset.

Kupperman, J.J. 1983. The Foundatin of Morality. London: George Allen\&unwin

Megawangi, Ratna. 2004. Pendidikan Karakter; Solusi yang Tepat untuk Membangun Bangsa. Bogor: Indonesia Heritage Foundation.

Mulyana, Rohmat. 2011. Mengartikulasikan Pendidikan Nilai. Bandung: Penerbit Alfabeta. 
Tirta Rahardja, Umar. 2005. Pengantar Pendidikan. Jakarta: Diterbitkan atas kerjasama Pusat Keguruan Depdiknas dengan Penerbit Rineka Cipta.

Undang-Undang Nomor 20 Tahun 2003 tentang Sistem Pendidikan Nasional.

Warsito. 2012. Pendidikan Pancasila Era Reformasi. Yogyakarta: Penerbit Ombak.

http://hizbut-tahrir.or.id/2009/12/01/jabar-masih-darurat-hivaids-dan-seks-bebas/.

http://hizbut-tahrir.or.id/2009/12/01/jabar-masih-darurat-hivaids-dan-seks-bebas/.

http://sites.google.com/site/otoehkasela/ikhlas-menurut-islam

http://www.al-islam.agussuwasono.com/artikel/aqidah/303-ikhlas-dan-bahayariya-html

www.wahdah.or.id/wis/index2.php?option=com_content\&do_pdf. 